in pure and applied research. The majority were on biological topics, a surprisingly large number on chemical and industrial applications, and only a few on metallurgy. This last group, however, was of high quality and indicated that replica techniques are now so far mastered as to open up great possibilities for metallurgists. P. Coheur and C. Habraken (Centre Nat. Rech. Métallurgiques, Liège) showed interesting but unexplained effects occurring during creep in steels; and $\mathrm{R}$. Castaing (Office Nat. de Rech. Aéronautiques, Paris) exhibited some beautiful oxide replicas showing the shape and orientation of newly formed $\mathrm{Al}_{2} \mathrm{Cu}$ crystals in the first stages of age-hardening of aluminium copper alloys ${ }^{11}$. In the same field of work, Castaing and A. Guinier described an ingenious scanning method of metallurgical analysis, in which an electron spot less than 1 micron in diameter is moved about a metal surface, and the emitted X-rays analysed, in order to find the smallscale variations in chemical composition of the surface.

In the biological field the most important papers were probably two from the United States and Sweden. E. de Robertis (M.I.T., Boston) described his recent work on the structure of the nerve axon, which proves to contain a mass of 'neuro-tubules', cross-banded like the larger fibres. On infection with poliomyelitis virus, the progress of dense particles along the axon can be followed in periodically isolated samples. F. Sjöstrand (M.I.T., and Karolinska Institute, Stockholm) described membrane structures found in the retinal rods of the guinea pig eye and in nerve tissue. These consist of rounded disks, some of which are as thin as $70-80 \mathrm{~A}$. at the edge, decreasing to $30 \mathrm{~A}$. at the centre. These are believed to be the unit structures of the rod outer segment. Membranes of about the same thickness were isolated also from peripheral nerve tissue; they may derive from the myelin sheath. The occurrence of a thin membrane, or epicuticle, in wool and other animal fibres was demonstrated by B. Philip and G. Lagermalm (Institute for Textile Research, Göteborg).

The work on viruses continues to increase in quality as well as extent, as shown in three papers. In bacteriology, two interesting contributions on the flagella and sub-flagella of various species were read by Miss W. van Iterson and A. L. Houwink (Laboratory for Microbiology, Delft) ${ }^{12}$. The remaining papers ranged from a study of the ageing of human skin to that of the nuclear apparatus of bacteria, of the membrane of myxomycete spores and of tissuecultured sarcoma. The chemical applications, which cannot be particularized, showed the increasing use of the electron microscope in industrial laboratories.

Papers were also presented on constructional improvements in the instrument, and related apparatus. Most interesting was a combined electron diffraction camera and microscope, due to M. v. Ments and Le Poole, having the great merit that the pattern dimensions are independent of object position and voltage fluctuation over an appreciable range. This promises to add greatly to the precision of electron diffraction work, especially by the reflexion method. It was demonstrated during the course of the Conference, as was the new Philips electron microscope and those built in the Delft Laboratory. W. A. Le Rütte showed an electrostatic microscope that employs an electron mirror as projector, giving a conveniently placed image with no distortion.

All in all, the Conference witnessed to the rapid progress made in Europe since the War in electron microscopy in all its aspects, theoretical as well as practical.

V. E. Cosslett

${ }^{1}$ Hillier, J., and Ramberg, E. G., J. Appl. Phys., 18, 48 (1947),

${ }^{2}$ Bertein, F., C.R. Acad. Sci., 224, 106, 560 (1947); 225, 801 (1947).

${ }^{3}$ Liebmann, G., Nature, 164, 149 (1949).

- Maréchal, A., Thesis, University of Paris (1948) (published Rev d'Optique).

${ }^{6}$ Hillier, J., J. Bact., 57, 425 (1949).

- Scherzer, 0., Optik, 2, 114 (1947); J. Appl. Phys., 20, 20 (1949).

'Gabor, D., Proc. Roy. Soc., 197 A, 454 (1949).

${ }^{8}$ Bretschneider, L. H., Proc. Kon. Ned. Acad. Wet. (in the press).

- Baker, R. F., and Pease, D. C., J. Appl. Phys., 20, 480 (1949); Claude, A., Harvey Lectures (1947-48) (in publication).

${ }^{10}$ Kellenberger, E., Experientia, 4, 449 (1948).

${ }^{11}$ Castaing, R., C.R. Acad. Sci., 228, 1341 (1949). 12 van Iterson, W., and Houwink, A. L., Biochim. Biophys. Acta (in

\section{SCIENTIFIC RESEARCH IN THE} UNIVERSITY OF BIRMINGHAM

THE nineteenth annual report of the Joint Standing fommittee for Research of the University of Birming fam, covering the session 1947-48, makes \& $x^{\prime}$ able contribution towards completing tha ger et pture of Great Britain's research effort bith ildemanded as a basis for any re-orientation. Thy immediate funds for research available to this chmittee are very modest, giving an income of only $£ 839$ for the session, but are now supplemented by grants from the University's general funds. The report details the conditions and procedure for applications for grants, and besides a classified list of research publications during the session, it includes a summary of researches completed during the session 1947-48, and reports on experimental cancer research at the Cancer Research Laboratories of the Medical School, financed by the Birmingham Branch of the British Empire Cancer Campaign and from the Radiotherapy Department of the United Birmingham Hospitals. Only a few of the researches completed during the year can be noted here.

In the Department of Mathematical Physics, the study of nuclear forces led to a method for treating the scattering of fast neutrons by protons. In the Department of Physics, besides cyclotron work in nuclear physics, work has been done on the optical absorption of crystal defects and impurity atoms in phosphor lattices, and on the dielectric strength of liquids for short pulses of voltage; assays have been made of the content of radioactive zine in biological specimens. The Department of Chemistry has carried out investigations on polymeric carbohydrates as substitutes for blood plasma, and has completed work on pneumococcus and mycobacterium tuberculosis polysaccharides which have a potential value as vaccines; work on fluorine chemistry has yielded a new range of organic fluorine compounds, some of which are of potential interest as non-inflammable lubricants, plastics, insulating materials, etc.

Work in the Department of Zoology on the nature and mechanism of tissue transplantation, immunity in animals, on the endogenous origin of virus-like bodies responsible for natural skin pigmentation in mammals and on the water relations of terrestrial isopods has progressed. In the Department of Botany, the effect of pretreatment of storage tissue on subsequent salt absorption, the salt relations of plant tissue and the biology of Phytophthora Fragarce in relation to red core disease of strawberries have been studied.

The Department of Mechanical Engineering completed the first stage of an investigation of the 
processes accompanying the sudden discharge of compressed gas from a cylinder into a pipe system. Creep and shrinkage phenomena in plain and reinforced concrete beams and columns and the use of light alloys for large structures were studied in the Department of Civil Engineering; while in the Department of Electrical Engineering the interaction of radio waves in the atmosphere, the motions of slow electrons in gases and the electrical properties of fluoro-carbons were investigated. The Department of Chemical Engineering reports preliminary investigations into the chemical nature of the resins and the 'free carbon' of coal tar, and studies of the vapourliquid and liquid-liquid relations of the system acetic acid-water-ethyl acetate. Long-term programmes on the theory of the constitution of alloys and on the deformation of metals and alloys were developed in the Department of Physical and Theoretical Metallurgy, and in that of Industrial Metallurgy investigations on the welding of aluminium alloys, the melting, casting and fabrication of copper-tin alloys and the effect of chemical composition, etc., on the crystal orientation and magnetic permeability of 3 per cent silicon steels were com. pleted.

\section{al: AMERICAN PHILOSOPHICAL SOCIETY RESEARCH REPORTS}

T HE Yearbook for 1948 of the American Philosophical Sopipy, in addition to the usual reports of standing ennmittees, auditor's reports, lists of lectures an ublications, awards of prizes and research grants, biographical memoirs, etc., includes classifted reports from the recipients of grants. The repprt of the Committee on Research details the gene 1 principles adopted by the Committee for determining the awarding of grants.

Among the reports from recipients of grants may be mentioned those from H. N. Russell on his work on behalf of the panel on orbits of eclipsing variables, which has led to the selection of thirty-five eclipsing systems for a first catalogue of eclipsing binary systems, from W. J. Luytens on the measurement of the proper motions of stars in the southern hemisphere north of declination $-40^{\circ}, \mathrm{H}$. H. Nininger on a magnetometer search for meteorites at Barringer Meteorite Crater, and W. J. Moore on his investigation of properties of the simpler aliphatic free radicals in the gas phase and in solution.

D. P. Costello reports on natural and induced heteroploidy in Triturus torosus and Triturus rivularis, two species of California salamanders; R. Rugh on a study of cortical changes in the egg of the frog, Rana pipiens, following fertilization; D. C. Smith on studies on the thyroid gland of fishes; W. D. McElroy on factors influencing the response of the bioluminescent reaction to adenosine triphosphate; $H$. Geiringer on the mathematics of heredity ; and R. S. Palmer on an investigation of mammalian ecology and populations in the upper Allagash region of Maine. Cytogenetic studies of the lethal $E$ complex, particularly as it affects a temporary reversion of Neurospora tetrasperma to an eight-spored $N$. sitophila type, are described by B. O. Dodge; a study of post-glacial forest migrations and climate in Western Canada by H. P. Hansen; cytogenetic studies on the guayule rubber plant and related species of Parthenium by R. C. Rollins and a survey of the algæ and economic algal resources of the Philippines by G. T. Velasquez. T. C. Schneirla summarizes his studies on army-ant behaviour and its biological basis; S. Wapner those on equivalence of stimuli and transportation in the rat; J. L. and E. M. Irvin their work on the interaction of certain antimalarial compounds with typical proteins and nucleic acids. F. Machlup describes his analysis of the economics of the patent system.

L. S. Cressman discusses his work on the archæology of the Klamath Indian culture of Oregon and its position in the Northern Great Basin Culture. Continued excavation of prehistoric remains in western Colorado is described by C. T. Hurst, an archæological, botanical and geological expedition to the Southwestern Yukon in 1948 by F. Johnson, and archæological investigations in southern Ontario, Canada, in search of the earlier stages of the Owasco culture, by W. A. Ritchie.

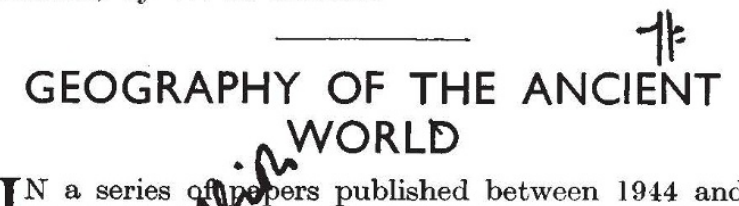

T a series oftpers published between 1944 and that a nolverger area of the world's surface was known in a tiquity than is commonly supposed. His conclupions fre based on a re-reading of passages in ancient authors, and some points deserve serious condiderdion. Prof. Stechow identifies "Iambulus Island" of Diodorus Siculus II, $55 \mathrm{ff}$. with Madagascar ${ }^{1}$. The astronomical and navigational data fit suggestions made by R. Hennig"; and the "vertical writing" of Diodorus's account would vouch for the Malay-Madagascar contact a thousand years earlier than the report of the Arab geographers. Stechow explains the reference to "seven islands" as an error due to the configuration of the Madagascar coast-line.

It is argued ${ }^{3}$ that Hanno, whose expedition is dated by Prof. Stechow to 537-525 B.C., did not turn back until reaching Mount Cameroon (which is described in a state of eruption), and that he met real gorillas, not baboons, chimpanzees or pygmies. Stechow postulates lacunæ in the Greek translation to explain the small number of days for the journey; the references to native drums, other details and a navigational point in Arrian all suggest that Hanno went beyond Mt. Kukulima (Sierra Leone) into an area $1^{\circ} \mathrm{N}$.

Frof. Stechow contends that in the Sixth Dynasty the Egyptians knew of the pygmies and the okapi of the Congo forests and, in the Eighteenth, of the greater Nile marshes. He believes that two of the four "Pillars" in the inscription of Ramses II are Ruwenzori and Mt. Cameroon. More fanciful are his identification of Ophir with Zimbabwe, Rhodesia, and his speculations on an Egyptian element in the Hottentot peoples.

Prof. Stechow interpretss Pliny "Natural History", IV, $96 / 7$ as referring to the mouth of the Oder, Cylipenus as the Bay of Stettin, Tastris peninsula as Ruegen, etc.

J. G. GRIFFIth

'Petermanns Geog. Mitt., 90, 84-5.

2 Hennig, R., in "Terrae Incognitae"' (1, 391 ff, second edition) admits a "certain "possibility" in this view. Contrast, however, J. 0. Thomson, "History of Geography", pp. 274, 281 (no reference to
Diodorus.

${ }^{3}$ Forschungen und Fortschritte, 21-23 (July 1947) and 24 (July 1948).

- Petermanns Geog. Mitt., Heft 3-4, 181 (1918).

${ }^{3}$ Forschungen und Fortschritte, 24 (Oct. 1948). 